\title{
The Impact of EU Funds on the Development of a Business Model for Small and Medium-Sized Enterprises
}

\author{
- Olinski Marian, Szamrowski Piotr, Luty Lidia
}

\begin{abstract}
The purpose of this paper is to assess the impact of grants received by companies on the formation of a business model. The study covered micro, small and medium-sized enterprises based in rural areas, which received support in the form of investment grants within the Regional Operational Programmes 2007-2013 for northern Poland. The research was done using a direct survey method, and covered a total of 155 companies. The results of the study indicate that the grant obtained affected implicitly the modification of the business model elements that are placed on the left side of the template of the Business Model Canvas. However, the tendency of enterprises to undertake an innovative activity usually means changes in their business model both on the left and right side. The greatest strength of the dependence was observed in the case of relationship between the size of the company and changes in the model elements. Mediumsized enterprises were the most active in this respect, when compared to comparison to micro and small businesses, and changed the largest number of elements of the business model due to the obtained grant.
\end{abstract}

Keywords: business model, grant, small and medium sized enterprises

JEL Classification: H81, L20, 038

\section{INTRODUCION}

In recent years a business model "Canvas" by Osterwalder and Pigneur has become a popular tool used both in practice and in numerous papers (e.g., Toro-Jarrin, Ponce- Jaramillor \& Guemes-Castorena, 2016, Dijkman, Sprenkels, Peeters \& Janssen, 2015, Wirtz, Pistoia, Ullrich \& Gottel, 2015, Obst, 2015, Zolnowski \& Böhmann, 2014, Da Silva \& Trkam, 2014, Hauksson, 2013, Muegge, 2012). In the databases an extensive scientific literature could also be found. It concerned the effects of support policies of micro, small and medium-sized enterprises with the use of instruments of a financial nature - for example, in the form of investment subsidies (e.g., Blackburn \& Karvis, 2010, Acs \& Kallas, 2008, Wren, 2005, Ramsden \& Bennett, 2005, Devins, 1999). However, there are no articles diagnosing (evaluating) the impact of the support in the form of investment subsidies reshaping business models in beneficiary enterprises. The following article is thus an attempt to fill up the resulting gap in the subject literature and business practice. Therefore, the research objective of the study is to assess the impact of grants on the formation of the business model. The study is limited to show the relationships between the components of the business model and the received support, limited to the sector of micro, small and medium-sized enterprises. This limitation is due to the fact that such entities are the main recipients of public aid within the framework of the EU funds. The results discover relationship 
between support and changes in business models. Instead of focusing only on the diagnosis of typical support effects like profit growth, income, employment, etc., they show the subsidies impact on changes in the business philosophy of the beneficiaries. Political decision makers, responsible for policy of supporting SMEs, need to be aware of how this financial assistance shapes business models in supported enterprises. Changes in the individual components of the business model, prejudge the long-term assistance effects. So, the results of the study constitute the guidelines helpful for making detailed decisions concerning the policy of SMEs support.

\section{THEORETICAL BACKGROUND}

The concept of the business model is accompanied by numerous controversies regarding its clarification. Magretta noted that the term of 'business model' is one of the most 'messy' concepts used in business (Magretta, 2002). Another debatable issue is the capability to develop such a definition that would satisfy both the scientific environment and business practitioners. As noted by Bis, 'in the subject literature, there is no single generally accepted definition of the business model since researchers dealing with the issue freely select various building blocks and develop multiple classifications' (Bis, 2013). Some of them argue that the development strategy is part of the business model, while others point to competitive strategy (e.g., Slowotzky, Morrison \& Andelman, 2000), and yet, another group of researchers believes that strategy should not be incorporated in the business model at all (e.g., Magretta 2002, Banaszyk, 2004). While analysing numerous definitions of a business model, one can infer that the core of the business model is value, in particular, the value for the customer and the company (e.g., Baden-Fuller \& Haefliger, 2013, Achtenhagen, Melin \& Naldi, 2013, Velu \& Stiles, 2013, Amit \& Zott, 2010, CasadesusMasanell \& Ricart, 2010, Linder \& Cantrell, 2000, Maxwell \& Rankin, 2007). Creating customer value and capturing value for the enterprise is at the heart of 'a business model'. However, there is no consensus on the number and types of elements forming a business model (Timmers, 1998, Mahadevan, 2000, Stewart \& Zhao, 2000, Afuah \& Tucci, 2001, Osterwalder \& Pigneur, 2010). It appears that the cause of the controversy is the excessive desire to include all matters relating to the functioning of the company in this concept. Due to the adoption in the research part of the business model of the constituents based on a popular Business Model Canvas created by Osterwalder and Pigneur (2010), for the purposes of this study, the definition given by both authors referring precisely to this model was taken. The definition has the following wording: 'business model is a description of the premises behind the manner in which the organization creates values and benefits from the generated value'. This definition emphasizes its two major functions, i.e., creating value and capturing value.

Another theoretical problem with serious practical implications is to define and establish the relationships between specific constituents of the business model. Most frequently one can distinguish from a few to a dozen elements of the business model, taking into account different criteria and the logic behind the grouping of the elements. The study used the 'Canvas' model proposed by the above-mentioned Osterwalder and Pigneur (Osterwalder \& Pigneur, 2010). Within their model, they distinguish the following nine building blocks of the business model: customer segments, value propositions, channels, customer relationships, revenue streams, key resources, key activities, key partners, and cost structure. 
The placement of individual elements in the model is not accidental. The right section is focused on the customer and, according to Osterwalder and Pigneur (2010), is based primarily on emotions. This part of the model includes:

- customer segments (selected groups of consumers, businesses or other organizations, on which the company focuses its activities in the range of offering and delivering value);

- customer relationships (usually understood as all of the company's activities aimed at acquiring new customers and retaining them);

- channel (the way enterprises communicate with and reach their customer segments to deliver a value proposition);

- revenue streams (money generated by a company from each customer segment).
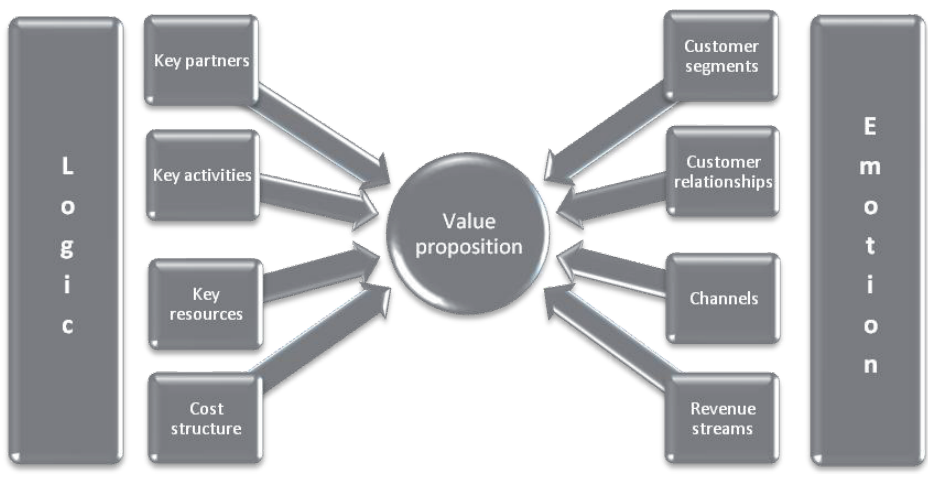

Fig. 1 - Osterwalder and Pigneur's business model Canvas template. Source: developed by the authors based on Osterwalder and Pigneur (2010).

A value proposition lies in the centre of the model, which is a bundle of products or services of value for a particular client. This proposal is the reason for which the customer selects the offer of a specific company and values it more than a competitive offer. It satisfies the customer's needs and solves a customer problem. Each individual value proposition consists of a bundle of products and/or services and their function is to meet the requirements of a specific customer segment. The value proposition may be diverse in nature. On the one hand, it may be innovative and represent an entirely new deal 'disrupting' the old order. On the other hand, it may only differ slightly from the existing market offer by, for instance, adding to the product or service new features and attributes (Osterwalder \& Pigneur, 2010).

The left part of the model contains the elements related to the company of existence of which the customer does not even need to be aware of. The present paper describes it as logical part of the model, in contrast to the right one based on emotions. This part of the model includes:

- key partners (the network of suppliers and partners who make enterprise operating);

- key resources (the most important assets necessary for the proper functioning of the business model); 
- key activities (the most important things that a company must perform with a perspective for creating and delivering value);

- cost structure (all costs generated by a business model).

The model used in the study, on the one hand, clearly highlights the role of the customer. On the other hand, however, it also exposes elements associated with the supply side of the company (key resources, activities, partners). This approach is more applicable to companies in which the elements play a significant role in business models - that means to mature entities. It often happens that companies that have been operating in the market for a short time do not possess developed resources, activities or stabilized relations with their partners.

\section{RESEARCH OBJECTIVES AND METHODOLOGY}

The study covered micro, small and medium-sized enterprises based in rural areas, which received support in the form of investment grants within the Regional Operational Programme 2007-2013 for northern Poland (warmińsko-mazurski, kujawsko-pomorski, pomorski and zachodniopomorski regions). Altogether 155 enterprises were surveyed. These companies received subsidies between 2008 and 2011 (76\% of the whole population). Studies were carried out in 2014 with the use of a direct survey method (only business owners and competent managers of these entities were surveyed). Small and medium-sized enterprises (SMEs) are defined in the EU recommendation 2003/361. The main factors determining whether a company is a SME are the number of employees and either turnover or balance sheet total. Small businesses have a number of specific market, financial, location, organizational and technological characteristics that define their operational and strategic behaviours, separate from large entities. This separateness is due to other, weaker market position in relation to large enterprises, their greater vulnerability to changes in the environment, the need for more rapid adaptation to changing external conditions, or to other objectives structure and motives of an activity which reflects the personal characteristics of the company's owner/manager. Limitations in the operation of small and medium-sized enterprises define the role of the state, which should promote actively the conditions for the functioning of the SMEs sector. One of simpler typologies of support instruments is the division into financial and non-financial ones. Investment grants represent a financial support instrument which, due to their non-refundable character, is a particularly desirable type of help sought by entrepreneurs representing small business. Therefore, further research part of the study is limited only to this kind of support.

The research objective of the study is to assess the impact of grants received by companies on the formation of the business model. The area of implementation of the assumed objectives has been delineated by the following research hypotheses:

1. The implementation of innovative undertakings facilitated profound modifications in the business model,

2. There is a positive relationship between the investment outlay and the resultant size of the grant and changes occurring within the business model, 
3. There is dependence between the size of the company and changes in the 'logic' part of the model. The larger the company, the greater the scale of changes in the left part of the model resulting from the investment made.

The data were compiled with the use of a statistical program STATISTICA. The following statistical procedures were applied to describe them: the analyses based on standard parameters and dependence test of selected variables (independence test, contingency coefficient C).

\section{RESULTS AND DISCUSSION}

The research was conducted in mid-2014 using a direct survey method, and covered a total of 155 companies from northern Polish, i.e., from the warmińsko-mazurskie, kujawsko-pomorskie, pomorskie and zachodniopomorskie provinces (out of 204 entities from rural areas which had received grants). Taking into account the fact that the research focused on rural areas (according to the Organisation for Economic Co-operation and Development (OECD), predominately rural areas are ones in which more than $50 \%$ of the population lives in rural communes. Rural communes are the communes with a population density below 150 inhabitants $/ \mathrm{km} 2$ ), the dominant group were entities from the warmińsko-mazurskie province that is characterised by a low number of municipalities. In the case of the pomorskie and the zachodniopomorskie provinces, a large group were headquartered in close proximity to the Tri-City and the City of Szczecin agglomerations.

The researched companies were grouped according to the following scheme: respondents could choose more than one factor that constituted a single building block of the model. For instance, within 'key resources', a total of the following four elements could be indicated: physical, intellectual, human, and financial. Therefore, values greater than nine could be obtained (Osterwalder and Pigneur's business model template is composed precisely of that number of elements). The obtained results allowed grouping the companies into those that implemented up to two changes both on the left and right sides, from three to five and from six to eight. After taking into account the ninth model element, i.e., value propositions, companies were grouped into those that implemented up to four changes in the business model modified by them, from five to eight and from nine to twelve changes. Moreover, companies were grouped according to criteria such as the investment outlay (a small amount up to 125 thousand $€$, the average amount ranging from 125 thousand up to 250 thousand $€$, a large amount from 250 thousand up to 750 thousand $€$, and a very large amount in excess of 750 thousand $€$ ) and the number of modifications in the business model. Also, the dependence between the size of the change in business model and the innovativeness of implemented projects and the size of the company was examined. As regards the generic arrangement, fixed assets were purchased in almost $70 \%$ of investments made. 
Tab. 1 - The basic numerical characteristics of selected indicators. Source: own

\begin{tabular}{|l|c|c|c|c|}
\hline \multirow{2}{*}{$\begin{array}{l}\text { Numerical } \\
\text { characteristics }\end{array}$} & Logic & Emotion & Total & $\begin{array}{c}\text { Investment outlay } \\
\text { [in thousands of } € \text { ] }\end{array}$ \\
\cline { 2 - 5 } & 8 & 4 & 12 & 1177.353 \\
\hline $\max$ & 1 & 0 & 1 & 7.919 \\
\hline min & 4 & 0 & 5 & - \\
\hline modal & 4 & 2 & 7 & 127.438 \\
\hline median & 4 & 0 & 6 & 67.591 \\
\hline first quartile & 6 & 3 & 10 & 184.044 \\
\hline third quartile & - & - & - & $93.7^{* *}$ \\
\hline average & $25.0^{*}$ & $75.0^{*}$ & $28.6^{*}$ & \\
\hline $\begin{array}{l}\text { variation } \\
\text { coefficient [\%] }\end{array}$ & & & & \\
\hline
\end{tabular}

* relative to quarterly deviation; $* *$ relative to standard deviation

A detailed list of the surveyed companies by type and nature of the performed project, company size, investment outlay and by the frequency of changes in the business model are shown in Table 2.

Tab. 2 - The selected elements characterizing the surveyed companies and changes in the elements of the business model. Source: own

\begin{tabular}{|l|c|c|}
\hline \multirow{2}{*}{ Specification } & \multicolumn{2}{c|}{ Frequency } \\
\cline { 2 - 3 } & Number & $\%$ \\
\hline Innovative project & 61 & 39.35 \\
\hline yes & 94 & 60.65 \\
\hline no & 6 & 3.87 \\
\hline The 'logic' part of the model & 109 & 70.32 \\
\hline low & 40 & 25.81 \\
\hline average & 136 & 87.74 \\
\hline high & 19 & 12.26 \\
\hline The 'emotion' part of the model & 0 & 0.00 \\
\hline low & 11 & 7.10 \\
\hline average & 104 & 67.10 \\
\hline high & 40 & 25.81 \\
\hline Total number of changes in the model &
\end{tabular}




\begin{tabular}{|l|l|l|}
\hline The investment outlay \\
\hline small & 36 & 23.23 \\
\hline average & 60 & 38.71 \\
\hline large & 25 & 16.13 \\
\hline very large & 34 & 21.94 \\
\hline Size & 44 & 28.39 \\
\hline micro & 64 & 41.29 \\
\hline small & 47 & 30.32 \\
\hline average & &
\end{tabular}

The obtained results of the study indicate that the investment made and the grant received on its implementation affected significantly the hitherto business model followed by companies, in particular within the area related to its left 'logic' part comprising key partners, key activities, key resources, and key costs. In all surveyed companies, at least one of the above-mentioned elements was altered. The nature of grants related mainly to the purchase of modern production lines, innovative and efficient machinery and equipment, or to other investments in modernizing production processes compels significant changes in the model being implemented, especially in its left part. Three companies (the record holders) have indicated up to eight factors that have been changed on the left side of the model (the surveyed enterprises were allowed to indicate more than one factor included in a single model constituent, and hence values greater than four were obtained). Interestingly, in the case of two investments, the investment outlay did not exceed 250 thousand $€$. Thus, even a relatively small amount can have a significant effect on changes in the business model followed by the company. In case of the third company, the investment value was in excess of one million $€$. As a result of the grant obtained, slightly more than $25.0 \%$ of the companies changed from six to eight elements that make up the left side of the model (Table 3). This result should be evaluated very positively. A significant fact is that this group comprised both companies that received relatively small grants and companies in which the grant amount exceeded half a million $€$. The amount of investment slightly affected changes in the use of the model elements, at least on its left side.

Tab. 3 - The impact of the investment outlay on changes in individual elements of the business model. Source: own

\begin{tabular}{|l|c|c|c|c|c|c|}
\hline \multirow{2}{*}{$\begin{array}{l}\text { Investment } \\
\text { outlay (€) }\end{array}$} & \multicolumn{3}{|c|}{$\begin{array}{l}\text { Frequency of changes in the } \\
\text { 'logic' elements of the model }\end{array}$} & \multicolumn{3}{|c|}{$\begin{array}{c}\text { Frequency of changes in the } \\
\text { 'emotion' elements of the model }\end{array}$} \\
\cline { 2 - 7 } & $<\mathbf{< - 2}>$ & $<3-5>$ & $<6-8 *>$ & $<0-2>$ & $<3-5>$ & $<6-8>$ \\
\hline $\begin{array}{l}\text { Up to 125 } \\
\text { thousand }\end{array}$ & 5 & 18 & 2 & 20 & 5 & 0 \\
\hline $\begin{array}{l}\text { From 125 to 250 } \\
\text { thousand }\end{array}$ & 0 & 27 & 7 & 32 & 2 & 0 \\
\hline $\begin{array}{l}\text { From 250 to 750 } \\
\text { thousand }\end{array}$ & 0 & 40 & 20 & 53 & 7 & 0 \\
\hline
\end{tabular}




\begin{tabular}{|l|c|c|c|c|c|c|}
\hline $\begin{array}{l}\text { Above } 750 \\
\text { thousand }\end{array}$ & 1 & 24 & 11 & 31 & 5 & 0 \\
\hline Total & 6 & 109 & 40 & 136 & 19 & 0 \\
\hline
\end{tabular}

Only six out of the 155 companies surveyed were in the group where up to two elements making up the left side of the model were changed (Table 3). This group included four micro companies and one small and one medium-sized entities, and the projects implemented by them were mainly non-innovative by nature (Table 4). The amount of the obtained financial support for these companies was at a low level (with one exception). By far, the largest group of companies were the ones that, as a result of the investment made, changed from three to five elements that make up the left side of the model (109 companies). The diversity of the companies in this group was significant, both in terms of the innovativeness of the projects implemented, the company size, and in terms of the amount of the grant received.

Interesting results can be observed while analysing the relationship between the number of the elements on the left side of the model and the innovativeness of the projects implemented (Table 4).

Tab. 4 - The impact of the nature of the implemented project on the magnitude of changes in individual elements of the model. Source: own

\begin{tabular}{|l|c|c|c|c|c|c|c|}
\hline \multirow{2}{*}{$\begin{array}{l}\text { Nature of the } \\
\text { implemented } \\
\text { project }\end{array}$} & \multirow{2}{*}{$\begin{array}{l}\text { Number of } \\
\text { companies }\end{array}$} & \multicolumn{3}{|c|}{$\begin{array}{l}\text { Frequency of changes in the } \\
\text { 'logic' elements of the model }\end{array}$} & \multicolumn{3}{|c|}{$\begin{array}{c}\text { Frequency of changes in the } \\
\text { 'emotion' elements of the } \\
\text { model }\end{array}$} \\
\cline { 3 - 8 } & & 2 & 41 & 18 & 53 & 8 & 0 \\
\hline Innovative & 61 & 4 & 68 & 22 & 83 & 11 & 0 \\
\hline $\begin{array}{l}\text { Non-innova- } \\
\text { tive }\end{array}$ & 94 & $4-2>$ & $<3-5>$ & $<6-8>$ & $<0-2>$ & $<3-5>$ & $<6-8>$ \\
\hline
\end{tabular}

Among the 155 companies surveyed, over 39.0\% made investment that was innovative by nature. Innovations should be understood as new products or production technologies applied for the first time in the company. In the group of companies that, as a result of the grant obtained, changed from six to eight elements that made up the left side of the model, $45.0 \%$ of the implemented projects were innovative. This means that a slightly bigger number of companies that changed the greatest number of model elements that make up the left side implemented non-innovative undertakings (55\%). Similar results were observed in the group of companies that had changed from three to five elements composing the 'logic' part of the model. Only in the group of companies that minimally changed the left side of the model, a slightly larger number of non-innovative investments was observed. The surveyed persons very clearly indicated the risk associated with the unsuccessful implementation of innovation, which mostly means that the value intercepted by the company is inadequate in relation to investment outlays made. Nowadays, the costs of creating, developing, and then shipping novel or modified products have risen tremendously. A far cheaper solution seems to be a modification of the business model followed by the company, which does not necessarily entail taking an innovative action. A business model 
itself becomes a new kind of innovation that complements a product, process, or organizational innovations in this aspect. As H. Chesbrough states, 'a better business model often will beat a better idea or technology' (Chesbrough, 2007). On the one hand, it is responsible for freeing the potential value embedded in new technologies and for converting it into market outcomes. However, on the other hand, as mentioned above, it can be a very profitable innovation in itself.

The results of the research show that $34.0 \%$ of medium-sized companies changed from six to eight elements forming the 'logic' part of the business model (Table 5), 26.6\% of small entities, and only $16.0 \%$ of micro-enterprises. Most frequently, these were micro, small and mediumsized entities that changed from three to five elements that make up the left side of the model. Micro-enterprises were the least active in terms of frequency of changes within the 'logic' model elements.

Tab. 5 - The impact of the company size on the frequency of changes in individual elements of the model. Source: own

\begin{tabular}{|l|c|c|c|c|c|c|c|}
\hline \multirow{2}{*}{$\begin{array}{l}\text { Company } \\
\text { size }\end{array}$} & \multirow{2}{*}{$\begin{array}{l}\text { Number of } \\
\text { companies }\end{array}$} & \multicolumn{3}{|c|}{$\begin{array}{l}\text { Frequency of changes in the } \\
\text { 'logic' elements of the model }\end{array}$} & \multicolumn{3}{|c|}{$\begin{array}{l}\text { Frequency of changes in the } \\
\text { 'emotion' elements of the model }\end{array}$} \\
\cline { 4 - 9 } & $<0-2>$ & $<3-5>$ & $<6-8>$ & $<0-2>$ & $<3-5>$ & $<6-8>$ \\
\hline Micro & 44 & 4 & 33 & 7 & 36 & 8 & 0 \\
\hline Small & 64 & 1 & 46 & 17 & 57 & 7 & 0 \\
\hline $\begin{array}{l}\text { Medium- } \\
\text { sized }\end{array}$ & 47 & 1 & 30 & 16 & 43 & 4 & 0 \\
\hline
\end{tabular}

The study analysed the impact of the grant obtained not only considering a division into the 'logic' and 'emotion' parts of the model, but also its impact on each element. The results achieved are shown in Table 6.

Tab. 6 - The impact of investment grants on selected elements of the Business Model Canvas. Source: own

\begin{tabular}{|l|c|c|}
\hline \multirow{2}{*}{ Business model elements } & \multicolumn{2}{|c|}{ Respondents } \\
\cline { 2 - 3 } & Frequency & $\%$ \\
\hline Key partners - the impact of support on the level of cooperation & & \\
\hline Investors (capital providers) & 9 & 5.8 \\
\hline Suppliers & 30 & 19.4 \\
\hline Other cooperating companies & 26 & 16.8 \\
\hline Key activities - the impact on technology, production methods, service delivery process, solving problems \\
\hline Specific problems & 31 & 20.0 \\
\hline Supply chain & 22 & 14.2 \\
\hline Production & 102 & 65.8 \\
\hline
\end{tabular}




\begin{tabular}{|c|c|c|}
\hline \multicolumn{3}{|c|}{ Key resources - improvement of resources } \\
\hline Physical resources & 147 & 94.8 \\
\hline Financial resources & 141 & 91.0 \\
\hline Human resources & 151 & 97.4 \\
\hline Intellectual resources & 12 & 7.7 \\
\hline \multicolumn{3}{|l|}{ Cost structure - reduction } \\
\hline Fixed costs & 25 & 16.1 \\
\hline Variable costs & 18 & 11.6 \\
\hline \multicolumn{3}{|c|}{ Customer relationships - implemented or strengthened type of relationship } \\
\hline Personal relationships & 9 & 5.8 \\
\hline Product co-developer & 27 & 17.4 \\
\hline Automation of relationships & 5 & 3.2 \\
\hline Self-service & 8 & 5.2 \\
\hline \multicolumn{3}{|l|}{ Channels - creation, modification } \\
\hline Own channels & 22 & 14.2 \\
\hline Channels shared with partners & 19 & 12.3 \\
\hline \multicolumn{3}{|c|}{$\begin{array}{l}\text { Customer segments - creation, modification } \\
\text { Diversification of activities }\end{array}$} \\
\hline Customer segmentation & 5 & 3.2 \\
\hline Diversification & 45 & 29.0 \\
\hline \multicolumn{3}{|c|}{ Revenue streams - change in methods of acquiring revenue } \\
\hline Fees for use (subscriber fees) & 0 & 0.0 \\
\hline Granting licences & 3 & 1.9 \\
\hline Intermediary commission & 0 & 0.0 \\
\hline \multicolumn{3}{|c|}{ Value proposition - changes in value proposition for customers } \\
\hline Qualitative elements & 91 & 58.7 \\
\hline Quantitative elements & 101 & 65.2 \\
\hline
\end{tabular}

The most extreme element of the left side of the model, i.e., key partners, changed only slightly as a result of the grant obtained. One in five surveyed companies pointed to suppliers as the type of partnership which had undergone some modifications. The buyer-supplier relationships to assure reliable supplies were indicated by the surveyed companies as the most important aspect in this element. Nearly $17.0 \%$ of respondents indicated a strategic alliance between non-competitors and co-opetition: strategic partnerships between competitors as a model element not impacted by the obtained grant. The obtained financial assistance affected least relationshipbuilding with key the partners understood as investors, or capital providers (Table 6).

Another element of the left side of the model is key activities, i.e., those that from the point of view of the business model are the most significant. Assuming that the central aspect of every business model is value, particularly aspects of the value proposition offered to the customer, the key activities should be those that are essential to the creation and presentation of customer 
value. These activities differ from the business type (the specificity of a particular business model). For manufacturing companies, these are often activities related to design, manufacture, handling of the product, etc. For service companies, these may be activities related to solving common or individualized customer problems, and for traders, the activity associated with matching partners. The company is primarily responsible for creating value through key activities. However, the market is increasingly characterized by the so-called 'phenomenon of co-creating value'. As noted by Prahalad and Ramaswama (2003), the future of competition is related to a completely different approach to creating value. This approach increasingly emphasizes those key activities that co-create value for the company and customers. The Internet becomes a useful tool in that respect (e.g., matching colours or specific components by customers). The whole idea of the so-called open source software is based on the concept of co-creation of value by customers (in this case by users) by means of performing key activities. The grants obtained had no effect on this type of behaviour (none of the respondents had noticed this effect). The most significant impact was observed in the area of production methods used and related changes in production technologies (65.8\% of responses, see Table 6). However, this support had a relatively little impact on changes in supply chain management as well as on changes in the process of providing services (introducing new methods of solving specific customer problems). This may be due to the fact that in the study, manufacturing companies prevailed and implemented projects practically meant investments intended to modernize production facilities.

The key resources constituted a building block of the left side of the business model which, due to the gained support, was subject to the most frequent modifications. It should be emphasized that creating value for the customer is possible only when the company has a set of capacities necessary for its creation. This set of capabilities is referred to differently and is composed of multiple components (in the subject literature, one can come across such terms such as key success factors, tangibles and intangibles, assets and skills, or resources which consist of everything that the organization knows and possesses). In this study, a set of capacities used to produce value for the customer was presented as follows: competences as a representative of intangible assets and resources as components of tangible assets. What the organization possesses are resources (physical and financial) and what "it" knows are skills and competencies (human and intellectual resources). Therefore, resources include manufacturing machinery and equipment, infrastructure and means of transport.

Managerial competences, in turn, comprise three major groups based on knowledge about customers (tastes, trends in changes concerning preferences, the size of the customer and non-customer populations), improved skills, environment (information about competitors, legal regulations, etc.), and about manufactured products (product range, manufacturing technologies, know-how, brands, patents, databases). The results obtained indicate that apart from intellectual resources more than $90.0 \%$ of the companies saw a favourable change in the area of the possessed financial, human, and physical resources. This condition indicates a positive impact of the grant obtained on this element of the model. What is important is that as much as $88.0 \%$ of the researched companies changed at least three elements that make up the company's key resources (Table 6). 
The last element of the left side of the model is connected with the cost structure and it describes all costs generated by a particular business model. Such activities as creating and delivering value, building and maintaining relationships with customers, or generating revenue contribute to their incurrence. The study distinguishes between fixed costs and variable costs. The respondents were asked to indicate whether the grant obtained could contribute to the reduction of their functioning costs. The results of the research show that there were very few of such companies. Nearly $12.0 \%$ of the entities examined in the study pointed to the reduction of their variable costs and $16.0 \%$ to the reduction of fixed costs. This result should not be surprising since the projects implemented by the companies related primarily to the purchase of machinery and equipment, or to investments made in modernizing production processes, and, therefore, they rarely contributed to reductions in costs. It is interesting that $40.0 \%$ of all entities that indicated a change in this model element, reduced both variable and fixed costs.

In contrast to the left side, the right side of the model comprising the customer relationships, customer segments, channels, and revenue streams elements changed under the influence of the obtained grants, however, to a much lesser extent. Out of the companies surveyed, only $33.0 \%$ modified one or two elements of this side of the model. This group consisted of companies that were very diverse both in terms of the implemented project type, grant amount and the company size. More than $55.0 \%$ of entities changed no single element of the right side of the model, whereas in the case of the left side, each of the examined companies changed at least one element (Table 3). The main cause of this phenomenon lies in the fact that the dominant group of the researched companies were manufacturing ones and, consequently, they were applying for grants for projects related mainly to the purchase of modern production lines, innovative and efficient machinery and equipment. The nature of the financial aid granted caused, therefore, a much greater tendency of the surveyed companies to change the left side of the model where the main emphasis is laid on the elements associated with those activities of the company the customer does not even need to be aware of. Out of the 155 researched companies, merely $12.0 \%$ changed from three up to five elements that form the right side of the model (the surveyed companies could indicate more than one factor being a single constituent of one model element and hence it was possible to achieve values greater than four, there were no such cases noted). They were also characterized by a strong commitment to change these model elements which were on the left side (of the seven most active companies which substantially modified the 'emotion' part of the model, two changed more than five elements on the left side, and five companies from three to five). Therefore, we can risk a statement that in the case of seven companies, the received grant affected practically every aspect of a change in the business model used, or initiated building a completely new model, in addition to the existing one. In four cases, the implemented project was innovative in nature and the investment value was less than 250 thousand $€$ in only one case.

The size of the company has little effect on the frequency of changes within the 'emotion' elements of the model. The smallest entities were the most active in this respect where in the group of the 44 surveyed micro-companies, $18.2 \%$ changed from 3 to 5 elements of the right side of the model. For the remaining two groups of companies, this result was at a level of around $10 \%$ (Table 5). Very similar results were obtained for the implemented project type. Innovative in- 
vestments meant only marginally greater involvement of companies in modifying the right hand side of the business model (13\% of companies that implemented innovative projects changed from 3 to 5 of such items - see Table 4). The importance of the investment outlay in case of the modification of elements, such as customer relationships, customer segments, channels, and revenue streams, were also of little significance. The most important modifications of the right side of the model concerned projects with the smallest investment outlay ( $20 \%$ of the companies in which from 3 to 5 elements were modified allocated less than 125 thousand $€$ for investments - see Table 3). Companies that implemented investments amounting exceeding 750 thousand $€$ came only second. In this group, almost 14\% altered from 3 to 5 'emotion' elements of the model. Changes in the business model on its right side did not mean that the company had to incur high costs.

The obtained research results have highlighted that the most extreme element of the right part of the model, i.e., customer segments, was the one of the four elements forming this part that had undergone only a slight modification. The received grant in the case of merely five companies influenced a decision to carry out customer segmentation and change this model element. The impact of grants on the diversification of activities, i.e., dealing with an additional customer segment, was emphasized only slightly more frequently $(29.0 \%$ of the surveyed companies indicated this option - see Table 6).

In the study, respondents were asked to indicate whether, as a result of the grant obtained, the hitherto relationship was strengthened or a new type of relationship with the customer was introduced. This element of the business model often corresponds to another component of that model, i.e., the channels. Customer relationships and channels under certain circumstances conceptually superimpose on each other, particularly where a direct distribution channel is operational, with no intermediate levels. According to Osterwalder and Pigneur (2010), a company should clarify the type of relationship it wants to establish with each Customer Segment. Relationships can range from personal to automated. The customer relationships may be driven by the following motivations: customer acquisition, customer retention, boosting sales. The obtained results of the study indicate that apart from co-creating products with customers, other elements contributing to developing relations with customers were indicated infrequently. This state of affairs may seem surprising, especially since nowadays customer relationships are an essential instrument of competition (Ungermann \& Myslivcová, 2014). These relationships are also affected by such elements as use of the internet in communication with current and prospect customers, quick response to customer signals with respect to offered products or liaising with customers at the stage of product conceptualization, design and manufacture (however, this particular element was modified as a result of the grant obtained slightly more often). As already mentioned, the marginal treatment of customer relationships was primarily caused by the grant type, which meant a larger vulnerability to a change in these model elements which are located on the left side.

Similar results were obtained with regard to another element of the Business Model Canvas, i.e., the channels. Supply logistics, production logistics, and distribution logistics fall into that category (Zarzycka, 2008). On the basis of the business model, distribution logistics is of particular interest. It encompasses flows of finished goods from the place of origin to the point 
of consumption in order to meet customer needs and requirements. The respondents were to indicate whether the received grant affected the channels used. Merely $14.2 \%$ of the companies modified or created new channels, e.g., selling via the internet, or hiring new salespeople. Even less because $12.3 \%$ of the companies, as a result of the grant obtained, modified contacts with their partners, such as, for instance, wholesalers, or partner stores (see Table 6). The reasons for this should be sought not only in the area of grants, but also in the characteristics of channels used by the surveyed companies. More than $68.0 \%$ of the surveyed companies operate in the manufacturing industry, mostly in low technology segments (especially in the warminsko-mazurskie province) with the predominance of indirect channels (producer-intermediary-customer) and long ones (a large number of intermediaries). Therefore, direct customer relationships may have less relevance.

The last item of the right part of the business model is revenue streams. In the study, they were only of marginal importance. The respondents were asked to assess whether the received grant had changed the way of obtaining revenues, e.g., by introducing a fee for the use (subscriber fee), new revenues from licensing, or by introducing brokerage commissions. Only three out of all surveyed companies indicated a change in this regard.

As mentioned, the central element of the model is the value proposition. The respondents were to indicate which elements of the value proposition changed as a result of the investment financing obtained. The obtained results indicate a slight advantage of quantitative elements that got modified after receiving the grant. Only slightly more than $65.0 \%$ of the surveyed companies pointed to this answer (Table 6 ). In this group, $80.0 \%$ of the companies laid emphasis on technical values, such as durability, efficiency and ease of use, and only $20.0 \%$ on economic values understood as those that changed due to the grant obtained. The qualitative elements defined as those that changed as a result of the funding obtained were indicated by slightly more than $58.0 \%$ of the surveyed companies. What is very important, only 28 companies did not change their value proposition neither within the quantitative nor within the qualitative groups of elements $(17.0 \%$ of the surveyed entities) as a result of the grant obtained. Out of this number, more than $89.0 \%$ implemented non-innovative undertakings and the obtained grant amount did not exceed 250 thousand $€$. The opposite extreme were the companies that due to the grant obtained changed both qualitative and quantitative elements. Out of the total number of companies, as much as $35.0 \%$ indicated this answer option. This fact should be assessed positively since it testifies that financial assistance for the SME sector brings measurable benefits in a form of significant modifications within the proposed customer value. What is interesting, the number of such companies exceeded those which indicated a change of only one element within the value proposition $(26.0 \%$ of the surveyed companies indicated only quantitative changes, and $21.0 \%$ qualitative ones). Among the companies that changed both elements that make up proposal value, nearly $47.0 \%$ implemented innovative undertakings, and $33.0 \%$ of entities received a grant for an amount greater than 250 thousand $€$. This group of companies included also a relatively large group of entities that received a grant of less than 100 thousand $€(43.0 \%)$. Changes in the customer value proposed were induced primarily by the innovative nature of the undertaking, and not by the amount of the support obtained. 
Taking into account the left and right sides of the model and value proposition, it was found that 28 of the 155 surveyed companies, i.e., slightly more than $18 \%$, modified from nine up to twelve elements of the model. In this case the investment made affected significantly the company's business model that had been implemented up to that moment, or the development of an entirely new one (Table 7). Merely $9.0 \%$ of companies modified four components of the model. This group was dominated by micro-enterprises performing mainly a non-innovative project. The investment outlays varied significantly in the most extreme cases. This amount significantly affects the frequency of changes in the elements composing the model in the group of entities which are the most active in this respect. Almost 31\% of companies in which the investment outlay exceeded 750 thousand $€$ modified from nine to twelve of all elements of the model. In only one company where the investment exceeded 750 thousand $€$, the frequency of changes of all model elements was contained within the smallest range (up to four elements). There were fewer entities with investment amounts ranging from one to three million (18\% in the group of companies that modified from nine to twelve model elements - see Table 7). In the group of companies that modified from five to eight of all model elements, the investment outlay varied considerably and only slightly affected the activity of the company in that respect. The value of the independence test amounting to $\chi^{2}=26.205$ with a low level of $p$-value indicates some dependence between the 'logic' part of the business model and the investment outlay. The contingency coefficient describing the strength of this dependence reaches the value $\mathrm{C}=0.380$. The test results $\chi^{2}$ do not exhibit, however, the existence of dependence between the 'emotion' part of the business model and the amount of investment (Table 10).

Tab. 7 - The impact of the investment outlay on the magnitude of change in the business model. Source: own

\begin{tabular}{|l|c|c|c|}
\hline \multirow{2}{*}{ Investment outlay $(\boldsymbol{(})$} & \multicolumn{3}{|c|}{ The frequency of changes in all elements of the model } \\
\cline { 2 - 4 } & $<\mathbf{0 - 4}$ & $<\mathbf{5 - 8}$ & $<\mathbf{- 1 2}>$ \\
\hline Up to 125 thousand & 4 & 18 & 3 \\
\hline From 125 to 250 thousand & 4 & 27 & 3 \\
\hline From 250 to 750 thousand & 5 & 44 & 11 \\
\hline Above 750 thousand & 1 & 24 & 11 \\
\hline Total & 14 & 113 & 28 \\
\hline
\end{tabular}

The type of the project being implemented affected the business model elements in two ways. Firstly, the group of companies that modified the highest number of model elements and those that restructured from five to eight of their components were similarly represented by those which implemented innovative projects as well as by those with non-innovative ones. Secondly, clear differences can be observed in the case of entities that changed up to four model elements. Within this group of companies, more than $85.0 \%$ implemented non-innovative projects (Table 8). The hypothesis posed by the authors assuming that the implementation of innovative undertakings fostered modifications within the business model was verified positively, though the dependence strength is small. The results of the independence test $\chi^{2}$ confirm that there is dependence between the total number of changes in the business model and the innovation of 
the project being implemented at a small (less than 0.016) level of significance. The contingency coefficient describing the strength of this dependence reaches a value $\mathrm{C}=0.225$ which indicates the average strength of this dependence. No significant relationship was found between the number of changes in the 'logic' and 'emotion' parts of the model and the type of the implemented project (Table 10).

Tab. 8 - The impact of the type of the implemented project on the magnitude of changes in the business model. Source: own

\begin{tabular}{|c|c|c|c|c|}
\hline \multirow{2}{*}{$\begin{array}{l}\text { The type of the } \\
\text { implemented } \\
\text { undertaking }\end{array}$} & \multirow{2}{*}{$\begin{array}{l}\text { Number of } \\
\text { companies }\end{array}$} & \multicolumn{3}{|c|}{$\begin{array}{l}\text { The frequency of changes in all elements of the } \\
\text { model }\end{array}$} \\
\hline & & $<0-4>$ & $<5-8>$ & $<9-12>$ \\
\hline Innovative & 61 & 2 & 47 & 12 \\
\hline Non-innovative & 94 & 12 & 66 & 16 \\
\hline Total & 155 & 14 & 113 & 28 \\
\hline
\end{tabular}

Among the most active companies in terms of changes that make up the business model template, the dominant group were medium-sized entities (Table 9). Out of the 47 surveyed medium-sized enterprises, $27.7 \%$ modified from nine to twelve elements of the business model. Only two medium-sized entities changed up to four model elements. Within the least 'active' companies, micro enterprises took the lead (10 entities). Also, the results of the test $\chi^{2}$ prove the assumption that there is dependence between the 'logic' part of the business model and the size of the company. The contingency coefficient describing the strength of this dependence reaches $\mathrm{C}=0.518$, which reflects a significant strength of the dependence. This strength is even greater in case of the dependence between the size of the company and the total number of changes in the business model resulting from the investment made and the grant obtained. In this case, the contingency coefficient describing it amounts to $\mathrm{C}=0.580$ (Table 10).

Tab. 9 - The impact of the company size on the frequency of changes in all elements of the business model template. Source: own

\begin{tabular}{|l|c|c|c|c|}
\hline \multirow{2}{*}{$\begin{array}{l}\text { The company } \\
\text { size }\end{array}$} & \multirow{2}{*}{$\begin{array}{l}\text { Number of } \\
\text { companies }\end{array}$} & \multicolumn{3}{|c|}{ The frequency of changes in all elements of the } \\
business model
\end{tabular}

A summary of the results obtained from the statistical procedures applied, i.e., examining the dependence between the following selected variables: implemented project type (innovative/ non-innovative), investment amount, the size of the company and the number of changes in the business model elements are shown in Table 10. 
Tab. 10 - The value of the statistic $\chi^{2}$ in the independence test of selected indicators with designated contingency coefficients $(C)$. Source: own

\begin{tabular}{|c|c|c|c|c|}
\hline $\begin{array}{l}\text { Selected elements describing the } \\
\text { surveyed companies* }\end{array}$ & $\chi^{2}$ & $d f$ & $p$-value & C \\
\hline \multicolumn{5}{|l|}{ Project type } \\
\hline logic & 0.764 & 2 & 0.683 & - \\
\hline emotion & 1.136 & 2 & 0.567 & - \\
\hline total & 8.232 & 2 & 0.016 & 0.225 \\
\hline \multicolumn{5}{|l|}{ Investment outlay } \\
\hline logic & 26.205 & 6 & 0.000 & 0.380 \\
\hline emotion & 1.225 & 6 & 0.976 & - \\
\hline total & 7.130 & 6 & 0.309 & - \\
\hline \multicolumn{5}{|l|}{ Company size } \\
\hline logic & 56.848 & 4 & 0.000 & 0.518 \\
\hline emotion & 3.940 & 4 & 0.420 & - \\
\hline total & 78.445 & 4 & 0.000 & 0.580 \\
\hline
\end{tabular}

\section{CONCLUSIONS}

In general, two different uses of the business model concept can be identified. One of the models refers to what we might call a static approach. In this approach, a business model is ultimately a blueprint - even a recipe - it fulfils important functions such as enabling description and classification (Demil \& Lecocq, 2010). The static view [of a business model] allows us to develop typologies and study relationship with performance. Osterwalder and Pigneur's business model template (2010) represents the most static approach where the dependence within the individual elements of the business model are presented fragmentarily, and virtually, there is no information about the mechanisms of strengthening and regulating the impact on the company's functioning (Doligalski, 2014). Its main advantage is that it is relatively easy to visualise the business. The transformational view, in turn, is a presentation of feedbacks in the system, and the vast majority of items are dynamic. In this case, the construction of the business model is much more challenging, though its analysis could lead to more innovative insights than in a static model. In the study, due to 'user friendly interface', Osterwalder and Pigneur's static template (2010) was used, though the authors are aware of the fact that a business model is not just a set of elements, but also the way the links are forged between them.

The results of the study indicate that the grant obtained implicitly affected the modification of the business model elements that are placed on the left side of the template. This is primarily due to its type. Purchases of modern production lines, innovative and efficient machinery and equipment, or other investments in modernizing production processes resulted in changes just on this side of the model. By far, the most common modifications resulting from the grant obtained 
concerned key resources. The right side of the Business Model Canvas comprising elements, such as customer relationships, customer segments, channels, and revenue streams changed under its influence, however, to a much lesser extent.

Only one in 10 companies modified a total of less than four model elements of Osterwalder and Pigneur's model (2010), and with regard to its left part, all companies changed at least one element.

Interesting results can be observed while analysing the relationship between the number of changed elements in the business model template and the innovativeness of projects implemented. The hypothesis no. 1 was verified positively, though the strength of dependence in this case was small and only at the level of total modifications in the business model. Only the least active companies in terms of changes in the business model implemented non-innovative projects. Within the remaining two groups of companies, types of implemented projects were very diverse and even for those most active ones in the area of modifications in the implemented business model the type did not reflect their innovative character. A high risk related to the implementation of an innovation causes that a far cheaper solution seems to be modifying the business model implemented in the enterprise, which is not necessarily related to undertaking innovative activities.

The hypothesis no. 2 was confirmed, but only partially, since the amount of grant affected slightly the manner of using elements of the model. Both in the group of companies that changed more than eight model elements and in the group which changed from six to eight elements, companies which obtained less than 250 thousand $€$ in grants and those which obtained significantly higher amounts were strongly represented. Thus, even a relatively small amount of the grant may materially affect the business model implemented in the company. Also, in the least active group of companies in terms of changes in the business model (up to four elements), the differentiation in the amounts of received grants and realized investments was significant.

The greatest strength of the dependence was observed in the case of the relationship between the size of the company and changes in the model elements. The hypothesis no. 3 was thus verified positively. The most active entities in this respect were medium-sized enterprises which, in comparison to small businesses, in particular to micro ones, changed, due to the impact of the grant obtained, the largest number of elements of the business model. This was especially true of its 'logic' part and the total number of changes. In the case of the model's 'emotion' part, the exhibited differences were not so great. It appears that management in medium-sized enterprises had a greater awareness of the role of the business model in achieving greater efficiency in operations, cost optimization, or in focusing on the client, and thus investments being made are more complex in nature. This issue, however, requires undertaking further detailed research.

The study included companies established in rural areas, and the vast majority of them operate in traditional sectors related to the agriculture and food processing, wood, furniture, or tourist industries. This fact largely contributed to the situation where most of the companies surveyed did not articulate a specific business model, and, therefore, lacked a process for managing it. According to the Business Model Framework (BMF) proposed by Chesbrough (2007), these type of companies operate as a business model of type 1. The Business Model Framework is a concept 
which entails both very simple business structures (and thus generating little value) as well as complex and advanced business models that are very difficult to copy (usually very valuable ones). When applying BMF, companies can evaluate the position of the model used in relation to its potential, and then determine the steps that seek to ensure its further development in the context of creating and capturing larger value. The business model incorporating the undifferentiated model is primarily based on price and availability and is aimed at customers for whom they constitute crucial factors while purchasing. Companies using the business model of type 1 offer mainly commodities in a similar vein to most companies operating in the market and offering similar products (Chesbrough, 2007). The majority of the surveyed companies represented precisely this type, or the ones located at level 2 and 3, which means that the company has some differentiation in its business model or the company develops a segmented business model (type 3). It could mean that the grant obtained often considerably affected changes in individual model elements. However, the lack of awareness among entrepreneurs and executives of its significance meant that the potential of this change was not fully exploited. It appears that it would be valuable to undertake research in this area as the authors focused primarily on determining the impact of the grant obtained for the various elements of the model, and not on managers' perception of its role in the logic of value creation. Quoting Teece (2010), there are a plethora of business model possibilities, some of which will be much better adopted to customer needs and business environments than others. Selecting, adjusting and/or improving business models is a complex art. Good designs are likely to be highly situational, and the design process is likely to involve iterative processes. New business models can both facilitate and represent innovation as history demonstrates (Teece, 2010). Osterwalder and Pigneur's business model template (2010) seems to be a very appropriate tool for redefining the business model, of course, not only in terms of the factor such as the grant obtained by the company. Its use is also justified by the ability to analyse enterprises with the exclusion of trade restrictions as well as the ease of identifying individual elements of the business model and thus there is large potential for its modifications.

\section{References}

1. Achtenhagen, L.,\& Melin, L., Naldi, L. (2013). Dynamics of Business Models Strategizing, Critical Capabilities and Activities for Sustained Value Creation. Long Range Planning, 46, 427-442. DOI: 10.1016/j.1rp.2013.04.002

2. Acs, Z. J., \& Kallas, K. (2008). State of literature on small-to medium-sized enterprises and entrepreneurship in low-income communities. Entrepreneurship in emerging domestic markets (pp. 21-45). Springer US.

3. Afuah, A., \& Tucci, C.L. (2001). Internet business models and strategies: Text and cases. McGrawHill Higher Education.

4. Amit, R., \& Zott, C. (2010). Business Model Design: An Activity System Perspective. Long Range Planning, 22, 216-226. DOI: 10.1016/j.lrp.2009.07.004

5. Baden-Fuller, Ch., \& Haefliger, S. (2013). Business Models and Technological Innovation. Long Range Planning, 46, 419-426. DOI: 10.1016/j.lrp.2013.08.023

6. Banaszyk, P. (Eds.). (2004). Model biz̨nesu jako podstawa zuarzqdzania strategicznego pržedsiębiorstwem. Poznań: Wydawnictwo Akademii Ekonomicznej w Poznaniu. 
7. Bis, J. (Eds.). (2013). Innowacyjny model biznnesowy - sposób na zwiększenie przewagi konkurencyjnej. Łódź: Wydawnictwo Społecznej Akademii Nauk.

8. Blackburn, R., \& Jarvis, R. (2010). The role of small and medium practices in providing business support to small-and medium-sized enterprises, Information paper, International Federation of Accountants, New York.

9. Casadesus-Masanell, R., \& Ricart, J.E. (2010). From Strategy to Business Models and onto Tactics. Long Range Planning. 22, 195-215. DOI: 10.1016/j.lrp.2010.01.004

10. Chesbrough H., (2007). Business model innovation: it's not just about technology anymore. Strategy\&Leadership, 35(6), 12-17. DOI: 10.1108/10878570710833714

11. DaSilva, C.M., \& Trkman, P. (2014). Business Model: What It Is and What It Is Not, Long Range Planning, 47, 379-389. DOI:10.1016/j.lrp.2013.08.004

12. Demil B., \& Lecocq, X. (2010). Business Model Evolution: In Search of Dynamic Consistency. Long Range Planning, 43(2-3), 227-246. DOI:10.1016/j.lrp.2010.02.004

13. Devins, D. (1999). Research note: Supporting established micro businesses: Policy issues emerging from an evaluation. International Small Business Journal, 18(1), p. 86-86.

14. Dijkman, R,M., \& Sprenkels, B., Peeters, T., Janssen, A. (2015). Business models for the Internet of Things, International Journal of Information Management, 35, 672-678. DOI:10.1016/ j.ijinfomgt.2015.07.008

15. Falencikowski, T. (2013). Spójność modeli biznesu. Koncepcja i pomiar. Warszawa: CeDeWu.pl.

16. Główny Urząd Statystyczny (2011).Obszary wiejskie w Polsce - Rural areas in Poland. Studia i analizy statystyczne. Warszawa-Olsztyn.

17. Hauksson, H. (2013). Metamodeling for Business Model Design: Facilitating development and communication of Business Model Canvas (BMC) models with an OMG standards-based metamodel, Stockholm University.

18. Linder, J., \& Cantrell, S. (2000). Changing Business Models: Surveying the Landscape, CambridgeMassachusetts: Accenture Institute for Strategic Change.

19. Magretta, J. (2002). Why Business Model Matter? Harvard Business Review 80(5), 86-92.

20. Mahadevan, B. (2000). Business models for Internet-based e-commerce: An anatomy. California Management Review, 42(4), 55-69. DOI:10.2307/41166053

21. Maxwell, A., \& Rankin, S. (2007). Building a Better Business Model. Ottawa: Alliance\&Technology Marketing Resource Centre - CATA.

22. Muegge, S. (2012). Business model discovery by technology entrepreneurs. Technology Innovation Management Review, 2(4), 5-16.

23. Obst, L. (2015). Utilizing the business model canvas to enable sustainability measurement on the business model level: an indicator framework supplementing the business model canvas, University of Twente.

24. Oliński, M. (2009). Wspieranie roz̧woju matych i średnich pržedsiębiorstw w regionie Warmii i Mazur. Olsztyn: Wydawnictwo Fundacja Wspieranie i Promocja Przedsiębiorczości na Warmii i Mazurach. 
25. Osterwalder, A., \& Pigneur, Y. (2002). An e-Business Model Ontology for Modeling e-Business. Slovenia: 15th Blend Electronic Commerce e-Reality.

26. Osterwalder, A., \& Pigneur, Y. (2010). Business Model Generation. Hoboken-New Jersey: John Wiley \& Sons, Inc.

27. Prahalad C.K, \& Ramaswamy, V. (2003). The Future of Competition: Co-Creating Unique Value With Customers. Boston-Massachusetts: Harvard Business School Press.

28. Ramsden M., \& Bennett R. J. (2005). The benefit of external support to SMEs: "Hard" versus "soft" outcomes and satisfaction levels", Journal of Small Business and Enterprise Development, 12(2), $227-243$

29. Slowotzky, A. J., Morrison, D. J., \& Andelman, B. (2000). Strefa Zysku. Warszawa: Polskie Wydawnictwo Ekonomiczne.

30. Stewart, D. W., \& Zhao, Q. (2000). Internet marketing, business models and public policy. Journal of Public Policy and Marketing, 19, 287-296. DOI: 10.1509/jppm.19.2.287.17125

31. Teece, D. J. (2010). Business Models, Business Strategy and Innovation. Long Range Planning, 43(2-3), 172-194. DOI:10.1016/j.lrp.2009.07.003

32. Timmers, P. (1998). Business models for electronic markets. Electronic Markets, 8(2), 3-8. DOI: $10.1080 / 10196789800000016$

33. Toro-Jarrín, M. A., \& Ponce- Jaramillor, I. E., Guemes-Castorena, D. G. (2016). Methodology for the of building process integration of Business Model Canvas and Technological Roadmap, Technological Forecasting \& Social Change, in press, http://dx.doi. org/10.1016/j.techfore.2016.01.009

34. Trojanowski, M. (2010). Marketing bezpośredni. Koncepcja-zarzadzanie-instrumenty. Warszawa: Polskie Wydawnictwo Ekonomiczne.

35. Ungerman, O., \& Myslivcová, S. (2014). Model of Communication usable for small and medium-sized companies for the consumer communication in social media. E \& $M$ Ekonomie a Management, 17(1), 167-184. DOI: 10.15240/tul/001/2014-1-013

36. Velu, Ch.,\& Stiles, P. (2013). Managing Decision-Making and Cannibalization for Parallel Business Models. Long Range Planning, 46(6), 443-458. DOI: 10.1016/j.lrp.2013.08.003

37. Wirtz, B. W., Pistoia, A., Ullrich, S., \& Göttel, V. (2015). Business Models: Origin, Development and Future Research Perspectives, Long Range Planning, in press, DOI: 10.1016/j.lrp.2015.04.001

38. Wren C. (2005). Regional Grants: Are They Worth It?, Fiscal Studies, 26 (2), 245-275.

39. Zolnowski, A., \& Böhmann, T. (2014). Formative evaluation of business model representations-The service business model canvas, Proceedings of the Twenty Second European Conference on Information Systems, Tel Aviv, 718-727. 
Contact information

Ph. D. Marian Olinski,

University of Warmia and Mazury in Olsztyn

The Faculty of Economics

Department of Organization and Management

E-mail:olinski@umm.edu.pl

Ph. D. Piotr Szamrowski,

University of Warmia and Mazury in Olsztyn

The Faculty of Economics

Department of Organization and Management

E-mail:peters6@wp.pl

Ph. D. Lidia Luty

University of Agriculture in Krakow

The Faculty of Agriculture and Economics

Department of Statistics and Econometrics

E-mail: rrdutka@cyf-kr.edu.pl 